\title{
Kinds of participation: Teacher and special education perceptions and practices of 'inclusion' in early childhood and primary school settings
}

\author{
Paper presented at the Making Inclusive Education Happen Conference, \\ Te Papa, Wellington, 28 to 30 September, 2009.
}

\section{Bernadette Macartney \& Missy Morton, University of Canterbury}

\begin{abstract}
This paper shares and interprets family narratives involving the exclusion of two disabled children within their early childhood and primary school settings. Interpretations of particular 'kinds of participation' that appear to be accepted as inclusive are explored. We argue that these interpretations have disabling effects on the children's learning and participation. We critique participation' as: 'presence', 'fitting in' and 'irrelevant or unimportant'. A 'Pedagogy of Listening', based on a critical, ethical and political approach to learning and teaching is presented as an alternative to deficit approaches to learning and participation (Dahlberg \& Moss, 2005; Rinaldi, 2006). New Zealand curriculum documents (MOE, 1996; MOE, 2007) are briefly considered in regards to their socio-cultural views of learning, teaching and participation and their positioning of disabled learners. A 'Pedagogy of Listening' and narrative approaches to assessment are considered in relation to their implications for inclusive New Zealand pedagogy.
\end{abstract}

\section{Kinds of Participation: Clare and Maggie's Stories}

Clare: Participation as physical presence and fitting in to existing arrangements When she was two years old Clare began attending Crossroads Childcare centre one morning a week. An education support worker (ESW) was employed by Clare's early intervention service (EIS) for the time Clare was in the centre. However, the EIS didn't employ the ESW during the school holidays and the centre wouldn't accept Clare attending without an additional adult, so Fran (Clare's mother) would accompany Clare to the centre during the school holidays and stay with her during the time she was booked in for. Although the centre would not allow Clare to attend without an additional adult, they expected Fran to pay for Clare's space when the ESW was not employed during the school holidays.

In reference to Clare starting to attend Crossroads Childcare Centre Fran said:

And when she first started there she didn't even know that other children existed, really. She was none the wiser to what was going on around her; she just sat, really... They had their mat time, as most places do, I suppose, and they had songs, morning tea and-play lunch, but it was all free play, there was nothing structured about it, and she learnt - she actually...she was like a little flower, I suppose. She sort of opened up a little bit and realized there was other children around her, from there. That was good.

Fran saw lots of value in Clare spending time with and around other children, although she would have preferred for the centre to have more 'structure'. Fran was perhaps indicating that the 'free play' approach used by the centre didn't respond as well to Clare's learning and participation as it 


\section{Bernadette Macartney \& Missy Morton}

may have for other children in the setting. However, Fran noticed and was excited by Clare's interest in other children and in what was going on "around her".

Individual Education Planning meetings (IEPs) were held regularly to discuss Clare's learning and participation at Crossroads Childcare Centre. These meetings were arranged, facilitated and hosted by the Early Intervention Service at their workplace rather than at the childcare centre. In reference to the Head Teacher from Crossroads being involved in Individual Education Planning (IEP) for Clare, Fran said:

The head teacher used to have to come to our IEP meetings in her lunch hour. She'd sit and eat her lunch and she'd come and that was great, but the teachers never actually took Clare off the teacher aide.

Fran was troubled by the lack of interest from the centre teaching staff in spending any time with Clare without the presence of the ESW or herself. I asked Fran if she felt any of the centre teachers had developed a relationship with Clare. Fran responded:

Not really. I mean, they were all great, and said: "Hello". Yeah and they'd speak to Clare on their way past, and stuff like that, but I don't think...they didn't really integrate her... you know, it never crossed their mind... it never crossed their mind to take her off the teacher aide, never.

I asked Fran what the Head Teacher from the pre-school and the early intervention staff talked about at the IEP meetings. In reference to the teacher Fran said she talked about:

What the other children were doing around her (Clare), and Clare becoming more part of the centre.

\section{Maggie Rose: Participation as irrelevant or unimportant}

In 2002, when Maggie was six years old, a special education professional came to school to carry out an "assessment" with her. The specialist had visited Maggie's classroom once or twice before, so was a relatively unfamiliar person to Maggie. The specialist took Maggie out of her classroom for the assessment. In her report, the specialist referred to her assessment as a "test". The "test" involved showing Maggie a series of illustrations, and asking her questions about each picture in turn. The stated purpose of showing and asking questions about each picture was to:

Determine Maggie's ability to maintain attention to task ... gain some knowledge of her expressive language abilities in connected speech, and gauge Maggie's ability to maintain the topic when asked a question.

In the "test results" written after the completion of the assessment, the specialist wrote:

Maggie-Rose's ability to maintain attention to task was limited. The test was abandoned after the $7^{\text {th }}$ card as she became fixated and very amused by the previous card. (A picture of a girl who had fallen down some stairs and broken her glasses). (Brackets in the original) 
Several weeks later the specialist came back to school and re-presented the picture card "test" that had previously been "abandoned". These were the/her "results":

Maggie demonstrated that she was able to maintain the topic when asked a question. However, this linked with her attention span. When presented with the remaining three pictures left over from the previous session, Maggie-Rose once again became fixated on the picture that she found amusing. Consequently the tenth picture card was abandoned.

Following this repeat assessment, the specialist wrote a plan for the classroom teacher recommending what she referred to as "targets" for Maggie at school. These "targets" included:

To facilitate Maggie-Rose to remain on-task it is recommended that a visual schedule be implemented to support and enhance organisation, functional communication and attention skills.

Further, that she will be expected to remain "on-task" for a given amount of time e.g. 5 minutes, then she is allowed to choose an "“off-task" activity for a given period of time. Once this time is up she will be expected to return "on-task", for a given period again...

That Maggie learns to ...Identify the days of the week; and to identify what day it is today, what day it was yesterday, what day comes after and what day comes before.

\section{Beliefs about Disability and Participation and Their Effects}

It is important to consider what messages about disabled children were being communicated within these situations and approaches, and how these messages influenced Clare and Maggie's learning and participation within their educational settings. The narratives of Clare and Maggie's experiences shared in this article contain a warning about solutions to educational exclusion resting within the adoption of particular teaching methods or approaches, such as Learning Stories. A Learning Story approach might not in and of itself avoid deficit discourses (Dunn, 2004). Without applying an understanding and critique of deficit discourses and how they operate to the experiences represented in this paper, it is unlikely that Clare and Maggie's experiences would be significantly improved. All licensed early childhood services in New Zealand are legally required to use Te Whaariki based narrative assessment, contextualized, holistic and reflective approaches to teaching and learning (MOE, 1998). Furthermore, they are expected to view and treat children as competent, capable and active learners (MOE, 1996). However, Bernadette's research, Kerry Purdue (2004) and other New Zealand early childhood researchers in inclusive education (Gunn, Child, Madden, Purdue, Surtees, Thurlow \& Todd, 2004) have documented many instances of deficit and 
exclusionary thinking and practices within New Zealand early childhood services, despite narrative assessment being embedded in curriculum and policy.

\section{Messages about participation and learning}

We suggest that the approaches described in Clare's early childhood centre and Maggie's school, are based on an image of the (disabled) child as a passive object that can be variously ignored and/or manipulated. In addition to being viewed as a passive object, Maggie's situation indicated a view of her as a novice and of learning and teaching as a straightforward process of the transference of knowledge and skills from expert to novice. Teaching was interpreted as the application of predetermined knowledge on the passive child with the underlying assumption that adults can control and manipulate the learning process towards predictable "results". These beliefs justify and encourage the isolation of the child from their relational (learning) context in ways that emphasise their perceived differences to the exclusion of other interpretations of the situation. Therefore the context of the child's learning is not believed to be or treated as important. The classroom or early childhood centre just happened to be where Clare and Maggie were, but their participation in the setting with and alongside others was not considered in ways that indicated where they were was important or central to Clare and Maggie's identities as learners and members of those environments.

\section{Assessment and participation}

Assessment can be used as a process for getting to know and learn about a child through an orientation towards understanding the child and their participation within their educational context and, particularly within early childhood education, other contexts of learning and inter-relationship such within their family and wider community contexts (Carr, 2001; MOE, 1996, 2007). Rather than taking particular assessment processes for granted, it is important for teachers to think about how the context/s in which assessments are carried out, the assessment focus and methods, and the goals stemming from assessment might foster inclusion or create barriers to participation and learning. A critical consideration of the assessment situations described above (Clare's IEP, Maggie's "test" and plan) can shed light on the influences on learning and participation of beliefs about what kinds of learning and knowledge are valued, who defines what is of value in the context and what the effects of these beliefs and the particular goals and practices recommended for learners are.

\section{Assessment and the privileging of a deficit knowledge base}

The knowledge underpinning Clare and Maggie's assessments demonstrated a pathological view of difference and disability as an internal and individual deviation from the norm and as 'other'. Rather than being indicative of Maggie's abilities, the specialists "results" and "targets" can be interpreted as evidence of a pre-existing deficit knowledge base and assumptions about disability and disabled children. For example, Maggie's enjoyment of what she considered to be a funny picture was interpreted and responded to as evidence of a 'fixation" and 'limited' attention to task. An emphasis on the remediation of perceived deficits through a focus on maintaining "functional" attention to task, responding in a "normal" way to someone else's topic or agenda, and engaging in "functional" communication represents a view of the learner as a passive object to be 
ignored and/or manipulated and shaped so as to fit in with dominant expectations about what is normal and appropriate behaviour (Graham, 2005). Looking at the situation from an orientation that positioned Maggie's learning and participation as being nested within a socio-cultural network and environment, would have allowed for other interpretations of her responses within this situation (MOE, 2007). Her ability to concentrate on and engage with a topic when it is meaningful, relevant and of interest to her became irrelevant and problematic within this assessment situation because the knowledge underpinning the situation positioned her as different and therefore lacking. Clare never spending time with teachers without the presence of her ESW or mother, and the teacher's interactions with her being fleeting, indicates that Clare was seen as 'other' and the teacher's not as responsible for her participation and learning compared to the way they viewed their responsibilities towards her 'normal' peers in the centre. It is likely that the causes of Clare's lack of involvement with her peers and teachers were assumed to be due to her individual 'problems' resulting from her 'special needs' and 'deficits' in mobility, communication and so on. Thinking that situates 'problems' with participation and learning within the learner, detract attention from recognizing and taking responsibility for the influences of the social, cultural and physical environment on a child's learning and participation. De-contextualising knowledge makes it possible for teachers to attribute behaviours to the individual without considering the limitations and effects of the approach and situation.

What counts as valued learning and knowledge and who defines what is of value? Within Clare and Maggie's situations it appears that the knowledge, opinions and contributions of special education 'experts' were privileged above those of teachers and their guiding curriculum documents. Clare, Maggie, their peers and family members were positioned as passive participants within these assessment and planning processes or not included at all. In Clare's centre, the responsibility for organizing and facilitating assessment and planning for Clare was taken by the Early Intervention Service, rather than the early childhood centre staff. Only one teacher from Clare's centre, the Head Teacher, traveled to and attended these meetings outside of the centre, and this was in her lunch hour. Although a goal of Clare's IEP was about her becoming more part of the centre, the practices of the centre teachers seemed to indicate a view that Clare's Education Support Worker and family were responsible for Clare's 'inclusion' within the centre. Although Clare's mother was dissatisfied with what she saw as Clare's isolation within the centre, the IEP process did not allow for her perspective to be shared and therefore responded to in ways that could have increased Clare's participation and connections within the centre. In Maggie's situation, the family, her classroom teacher and teacher aides were only involved as recipients of the specialist's recommendations and reports.

\section{Deficit views and kinds of participation}

Viewing the child's "deficits" or "impairment/s" as being the defining influence on their behaviour, participation and learning diverts teacher's attention away from the influences that other people, dominant cultural assumptions and the environment have on a child. When an emphasis on perceived deficits within the 'disabled' individual remains unquestioned and is accepted by teachers, attention can also be detracted from 
interpreting the child and their behaviours positively, viewing the child as a full member of the classroom or centre community, and recognizing and responding to opportunities for the child's contribution, participation and learning. Instead, the situations presented in this article suggest that deficit views draw teacher's attention away from the context of learning and through this process the disabled child's limited access to full participation in the curriculum and the opportunities offered in the environment is obscured and/or justified.

In Clare's situation, it appears that her participation and learning were viewed as being catered for through her physical presence in which she and the non-teacher adults that accompanied her were expected to fit in with existing arrangements. In other words, the major contribution of the centre was that Clare's presence was tolerated with little or no consideration given to how the social and physical environments could change, adapt or respond to Clare as a learner and member of the centre community. In Maggie's situation, teachers allowed outside 'experts' to withdraw her, carry out assessments and make recommendations that ignored her as an active learner within a classroom learning community context (MOE, 2007). In this way, Maggie's participation was seen as unimportant and irrelevant to her learning. Instead, she was expected to fit in to normalising views and expectations that positioned her as inattentive, fixated, and uncooperative and to be subjected to an 'on-task' - 'off-task' regime that would have further isolated her from spontaneous and meaningful interactions with her peers within her classroom setting.

\section{Pedagogy of Listening}

Rather than pathologising difference, 'pedagogy of listening' acknowledges and invites differences, diversity, ambiguity, uncertainty and engagement with the 'other' in the pursuit of an inclusive and democratic education and society.

\section{An ethical and politicized approach to education}

Dahlberg and Moss (2005) argue that, consistent with a socio-cultural approach to learning and teaching, ethics and education should be understood as localized, shifting and changing in response to and in relationship with particular groups of people in time, space and place. They suggest that pre-schools as social and cultural institutions: “...can be understood, first and foremost as forums, spaces or sites for ethical and political practice - as 'loci of ethical practices' and 'minor politics"' (Dahlberg and Moss , 2005, p.2). This view acknowledges that power relations exist and are played out within educational settings. Furthermore, the workings of power are influential in terms of their effects on children's learning, participation, exclusion and/or inclusion (Gunn et. al, 2004). Rather than believing that educational settings function in a 'neutral' fashion, it is suggested that they operate in ways that reproduce and/or resist inequality and exclusion (Gunn et.al, 2004; Macartney, 2008a, 2008b; Mac Naughton, 2005; Moss \& Petrie, 2002; Rinaldi, 2006). Practices underpinned by a belief in the 'neutrality' of education do nothing to challenge unequal power relations and thus reproduce exclusion. Dominant power relations marginalize minoritized groups in society through viewing and positioning them as 'other' in relation to expectations of acceptable behavior, beliefs, appearance and various indicators or markers of what is 'normal' (Bishop, Mazawi \& 
Shields, 2005). The 'other' is expected to conform to the dominant group's set of universal ethics, rules, norms, values, codes and dominant understandings while the dominant group continue to benefit from society operating according to their ways of thinking and being.

Underpinning a 'pedagogy of listening' is an ethical and moral commitment to every child's right to be valued, accepted, exercise agency, contribute, learn, fully participate and belong (Dahlberg \& Moss, 2005; MOE, 1996). A pedagogy of listening argues that teachers must consciously work from an ethics of care and obligation to 'others', rather than unconsciously supporting and reinforcing practices that privilege the status quo and place anything that doesn't fit at the margins. Dahlberg and Moss (in Rinaldi, 2006, p.15) suggest that an approach to teaching and learning based on a 'pedagogy of listening' creates a space where:

...politics and ethics come together in an approach to education which rejects the regulatory bonds of developmental classifications and education as transmission and normative outcomes, and which emphasises the importance of otherness and difference, connectedness and relationships.

Central to a pedagogy of listening is the active rejection of universal, normative, developmental images of 'the child' and education, in preference for a socio-cultural view of education that recognizes and is comfortable with the complexity, diversity, and uncertainties within social systems as they are lived out and experienced on a local level, in particular contexts.

\section{Listening and inclusive approaches to learning and participation}

Veck (2009) describes a close relationship between listening and inclusion, and between not-listening and exclusion.

First, labeling learners, in terms of what has been deemed deficient within them, can form a barrier to listening. Second, when learners are not listened to, they are denied the opportunity to contribute, to enrich or to challenge the culture, organization and character of educational institutions and are, as a consequence, excluded within these institutions: they are in but not of them (Veck, 2009, pp.141-142)

There is more involved than educators listening to learners. Veck argues that educators and learners must listen to each other, and listen to themselves:

I argue that listening within education begins when learners and educators attend to each other as unique individuals. Such listening is conditioned, I contend, by the willingness of educators and learners to listen to the words they speak and to hear the discourses that dominate their educational institutions (Veck, 2009, p.142)

A powerful example of 'conditioned listening' is the impact of the dominant discourse of 


\section{Bernadette Macartney \& Missy Morton}

difference as deficit. In this discourse disabled students are no longer known as their own selves, but rather as representatives of their labels or diagnoses. Both successes and failures are not theirs; successes and failures merely confirm or challenge correct diagnostic processes, categories and interventions. The application and circulation of deficit labels extends beyond the professional's ability to control its meaning and effects. The meanings of labels are constructed and re-constructed through everyday use, gaining exclusionary power in and through the everyday use.

If listeners hear, in the words we speak, only further proof of our 'learning difficulties' or 'special needs', then our words are lost in reductive interpretation and so are we. All that is seen and heard is the label fixed upon us; who we are is rendered invisible (Veck, 2009, p.144).

There is an irony in this outcome. In the same act that renders a student invisible, they are also highly visible, though not as an individual:

When a stereotype or label becomes a signifier for who we are, we find ourselves doubly burdened by the curse of enforced invisibility and enforced visibility, of being heard but not being listened to. It is not simply that others 'refuse to see' or to listen to us for who we are, but that they insist on seeing us or hearing our words for what we and they are not, for 'everything and anything except' who we are. It is a question of who is made invisible and what is made visible: of who is lost in interpretation and what is created in interpretation. Reduced to a stereotype or label, we have to struggle for recognition, for the right to appear and to be listened to as unique individuals, and against the obscuring of our uniqueness (Veck, 2009, p.144).

The attentive looking and/or listening advocated by Veck is distinct from and in contrast to the surveillance described by Foucault (1977). Veck (2009) uses Weil (1951/1973) \& Murdoch's (1970/2003) notions of an 'attentive gaze' that is just and loving, in his conception of teacher's developing a listening orientation within their practice:

Through their understanding of 'attention', Weil and Murdoch suggests that by listening to others we might move from what Foucault (1977) called a 'disciplinary gaze' to what might be described as an attentive gaze. Where a 'disciplinary gaze' is directed to 'what' someone is judged to be, an attentive gaze looks to what is not and perhaps cannot be known about them: who they are in and to themselves. The former seeks to control, the latter to understand. The casting of a 'disciplinary gaze' marks the end of listening, an attentive gaze its beginning. When a label of special educational need or learning difficulties comes to define who someone is, a sea of human possibility is veiled in a thick fog; only an attentive gaze can see past this fog, for this gaze is always directed towards, and always seeks to reveal, originality and mystery (Veck, 2009, p.147).

Veck claims it is not possible to simultaneously direct both a disciplinary gaze and an attentive gaze. Within attentive listening lies the possibility of transformation: 
In tenderness, a listener may move from thinking of a speaker's differences as deficiency and come to consider the ways in which these differences might make a difference to them. At this moment, the speaker becomes entirely and unalterably connected to the world, for they have influenced the ways others act within the world and have thereby-in however small a way-contributed to it. (Veck, 2009, p.147).

In this view of listening and attending, teachers are learners and learners are teachers. Learning to listen in this way is possible, perhaps even required, within a socio-cultural view of learning and perspective on education. Smith \& Barr (2008) suggest that particular ways of relating and communicating are embedded within professional discursive networks. Special education can be viewed and described as a professional network with its own set of discursive practices (Skrtic, 1991). Smith and Barr noted the significant impact of the 'ideology of the individual' within special education and, we would add developmentalist approaches to learning and teaching (Fleer, 2005), and argued that,

Progress towards effective educational inclusion requires conceptualizing the learner in social terms, and social behaviour as socially embedded and socially meaningful - something of a paradigm shift in Northern Irish education" (Smith \& Barr, 2008, p.405).

Moreover, shifting from a disciplinary gaze to attentive listening requires the reconceptualising of learning as predictable and as more than merely what is taught (Smith \& Barr, 2008).

\section{Embracing complexity and uncertainty}

Rather than ignoring and marginalizing difference, viewing ethics and politics/power as central to education involves recognizing and responding to the diversity and complexities that exist within education and society (Gunn et.al, 2004; Robinson \& Jones Diaz, 1999). A pedagogy of listening involves an orientation to teaching and learning that expects, invites, encourages and embraces diversity, difference, ambiguity and uncertainty. Recognizing and valuing diversity contrasts with deficit pedagogies that are based on a predetermined, universal body of knowledge that privileges one way of being and enshrines it as the 'norm' (Macartney, 2007; 2008a). Rinaldi (2006, p. 70) describes 'listening' as a social and relational process in which the expectations and behaviors of teachers towards children are "orientative" and responsive, rather than pre-determined and prescriptive. In order to orient themselves through their teaching, Rinaldi (2006) suggests that teachers analyze and interpret children's lived experiences from an open, curious and questioning stance. This orientation is in contrast to teachers perceiving themselves to be the experts and knowers in regards to children's learning, aspirations and participation.

\section{Acknowledging our own social and cultural positioning in relation to Others}


Teaching through a pedagogy of listening involves being alert to voices, perspectives and ways of being that are outside of our usual and taken-for-granted ways of being in, understanding and experiencing the world. Dahlberg \& Moss (2005) suggest that, although we can't grasp or know others in the same ways that we know and experience ourselves and those similar to us, we have an ethical obligation to recognize, respect, engage with and learn from difference and diversity in our work and lives. Respectful engagement involves acknowledging the limits of our ability to fully understand the other, at the same time as fulfilling our obligations to listen and respond in ways that do not ignore and over-ride the experiences, rights and needs of people who we perceive to be different from ourselves. Practice based on an ethics of care and obligation to the other includes actively resisting exclusion and dismantling barriers to other's learning, participation and inclusion as a central role of teachers (Dahlberg \& Moss, 2005; Mac Naughton, 2005; Robinson \& Jones Diaz, 1999).

\section{A pedagogy of listening and the transformation of participation}

Both Margaret Carr (2001) a New Zealand curriculum and assessment researcher and one of the key authors of Te Whaariki - The New Zealand Early Childhood Curriculum (MOE, 1996), and Carlina Rinaldi (2006), an early childhood theorist, researcher and practitioner from Italy, emphasise the transformative nature and potential of education and learning within socio-cultural contexts. Carr (2001) describes 'learning' as a process that involves the 'transformation of participation'. Rinaldi (2006) also points to an understanding of learning as being about the transformation of participation when she emphasises the role of dialogue and inter-relationships in the social co-construction of knowledge within educational settings. Her explanation of 'dialogue' includes both teachers and children as:

...having a capacity for transformation... It is an idea of dialogue not as an exchange but as a process of transformation where you lose absolutely the possibility of controlling the final result (Rinaldi, 2006, p. 184).

Therefore, learning and the construction of knowledge are viewed as being embedded within an inter-relational context that has the potential to transform meaning and action (Carr, 2001; MacNaughton, 2005; MOE, 1996; Rinaldi, 2006).

Dahlberg and Moss (2005, p. 101) discuss a pedagogy of listening in relation to its overt commitment to opening up a "radical dialogue" amongst adults and children who are connected through a shared learning space and community. They suggest that what makes dialogue 'radical' within a context of a pedagogy of listening is the absence of the teacher as the expert knower:

In radical dialogue, based on listening, as a teacher you have to participate together with the child, entering a space together where both teacher and child are actively listening and trying to construct meaning out of the situation (Dahlberg \& Moss, 2005, p. 101). 
When we recognise and bring our preconceived understandings of learning, knowledge and participation into question, we can act and respond towards others in less predetermined and oppressive ways (MacNaughton, 2005). This includes noticing and valuing our differences and consciously working to identify, challenge and remove barriers to children's learning, contributions and participation that draw from exclusionary beliefs, assumptions and practices.

\section{Te Whaariki (MOE, 1996), The New Zealand Curriculum (MOE, 2007) and Transformative Pedagogies}

An understanding of and response to learning as the 'transformation of participation' is reflected in New Zealand's mandated curriculum documents Te Whaariki - The New Zealand Early Childhood Curriculum (MOE, 1996) and The New Zealand Curriculum (MOE, 2007). Both of these documents emphasise teacher, early childhood service and school roles in recognising and valuing diversity and in empowering children and their families. These approaches can be viewed as embodying a pedagogy of listening in terms of their close attention and orientation to the lived experiences and contexts of learning and teaching.

\section{The principles and strands of Te Whaariki}

The Principles and Strands of Te Whaariki communicate the ethical obligations of early childhood educators towards all young people and families participating within early childhood education settings (MOE, 1996). In particular, the curriculum Principles require teachers to, recognize and foster the empowerment of young children as they learn and grow, practice in ways that reflect a holistic understanding of children and their learning, acknowledge the integral place of the wider world, community and family in children's learning and participation, and view learning as an intersubjective process where children: “... learn through responsive and reciprocal relationships with people, places and things" (MOE, 1996, p.14). The curriculum Strands represent broad goals focusing on infants, toddlers and young children experiencing a sense of belonging and well-being, as being engaged in active exploration, as having and developing diverse ways to communicate and express themselves, and as having their contributions valued and developing a sense of responsibility towards others. Within a Te Whaariki based framework, assessing children's learning and evaluating teacher's practices, involves telling, documenting, discussing and interpreting stories of learning and practice in action within the local social, physical and cultural context/s in which learning and teaching are happening (Carr, 2001).

\section{The New Zealand Curriculum (MOE, 2007)}

The New Zealand Curriculum provides a foundation, framework and direction for teachers and schools in relation to what is important, how learning and teaching are conceptualised, the teacher's image of the child, and the implications of these for teaching practices and orientation. The Curriculum (MOE, 2007) draws from "credit"based, social justice and human rights discourses to describe and respond to children's learning and participation. The Government's espoused vision for New Zealand school students is that they will develop into: “...confident, connected, actively involved, 
lifelong learners" (MOE, 2007, p. 7). The Curriculum Principles include an expectation that:

The curriculum has meaning for students, connects with their wider lives, and engages the support of their families, whaanau and communities... (and that) ...students' identities, languages, abilities, and talents are recognised and affirmed... (MOE, 2007, p. 9).

As such, the Curriculum directs teachers to take responsibility for the learning and participation of all children. This includes children who have been labeled as having 'special educational needs'. The curriculum Values and Key Competencies include the expectations that schools will create environments where students develop a shared sense of belonging, take responsibility for themselves and others, and develop an understanding of and respect for equity, diversity and human rights (MOE, 2007).

The Curriculum describes the orientation of the effective teacher as: "cultivating the class as a learning community. In such a community, everyone, including the teacher, is a learner..." (MOE, 2007, p. 34). Children are viewed as active participants and coconstructors of their learning. This positioning of teachers as learners and students as teachers, challenges the idea of teachers and special education personnel being the only 'experts' when it comes to understanding and making decisions about the teaching, learning and participation of students. Rather than drawing from a narrow 'expert model', the Curriculum emphasises learning as a socio-cultural process of inter-relationship involving the co-construction of knowledge. In this regard, the Curriculum states that:

Learning is inseparable from its social and cultural context. Students learn best when they feel accepted, when they enjoy positive relationships with their fellow students and teachers, and when they are able to be active, visible members of the learning community (MOE, 2007, p. 34).

A socio-cultural view recognises and privileges diversity, dialogue, multiple perspectives, divergent viewpoints and negotiation as corner stones of an effective pedagogy and curriculum (MOE, 2007; Rinaldi, 2006). Rather than constructing children's learning and development as universal and children as passive recipients of knowledge, the Curriculum describes effective pedagogy as stemming from an understanding as “teaching as inquiry” (MOE, 2007, p.35). 'Teaching as inquiry' conceptualizes teaching and assessment as processes through which teachers are consciously noticing and responding to the student's learning within their specific context. We argue that such a socio-cultural view presents a challenge to individualised, deficit discourses that explain the success or failure of a child as being caused by factors within the individual student (Ballard, 2004; MacArthur, Kelly \& Higgins, 2005). Furthermore, the onus for a student's 'success' or 'failure', and their levels or kinds of participation, must be on the social and cultural environment within which they are situated and a consideration of how that environment impacts on their learning, participation, inclusion and/or exclusion.

Te Whaariki \& The New Zealand Curriculum: What's the problem? 
Although the New Zealand curriculum documents state their support of inclusive pedagogies for all children's learning and participation, disabled children still commonly experience and are affected by deficit based assumptions, thinking and practices within their early childhood and school settings (Macartney, 2002, 2007, 2008a, 2008b; MacArthur, Kelly \& Higgins, 2005; MacArthur, Purdue \& Ballard, 2003; Rietveld, 2005).

Deficit views and pedagogy draw from traditional individualized, psychological and developmental beliefs and knowledge about learning and development (Fleer, 2005). Although the texts of Te Whaariki (MOE, 1996) and the New Zealand Curriculum (MOE, 2007) advocate for socio-cultural approaches to education, there are tensions within the curriculum documents, classrooms and early childhood centres between traditional, individualized, and socio-cultural conceptualizations of learning and teaching (Dunn, 2004; Fleer, 2005; Moore, Molloy, Morton \& Davis, 2008). For example, Moore et.al (2008) point out that the key competencies in the New Zealand Curriculum, which conceptualise competence as the on-going development of dispositions for life long learning are at odds with the fragmented, prescribed and hierarchical approach to learning communicated in the learning areas and levels later in the document. They state (Moore et.al, 2008, p. 5) that:

Within the one document it is thus possible to identify policy statements supporting inclusion and approaches to curriculum, assessment and pedagogy that both work for and against inclusion.

At the same time as recognizing and celebrating the fact that our curriculum documents and writers have risen to the challenges of positively responding to diversity within society and amongst learners inclusively, there are still some structural problems within those texts and supporting policies and the messages they convey about teaching, learning and inclusive pedagogies as a result (Millar \& Morton, 2007).

The New Zealand Government agrees that there is a widespread, unquestioned acceptance and dominance of deficit and personal tragedy discourses related to disability in our society and that this is a problem (Millar \& Morton, 2007; Ministry of Health, 2001). Teachers, parents, educational administrators, researchers and curriculum authors are not immune to these deficit discourses. This situation makes it perhaps particularly problematic that neither of the curriculum documents overtly addresses unequal power relations, nor the role that education performs in reproducing inequalities, particularly in relation to the marginalization and exclusion of disabled people in society. To the contrary, both documents are silent about disabled children as a marginalized group. Disabled children are generally subsumed within the groups "students', "children", "infants", "toddlers" etc... within the curriculum documents. Although this could be viewed as an attempt not to separate disabled children and their rights to access the curriculum from the rights of non-disabled children, the effect is to not consider and therefore address issues related to the exclusion and marginalization of disabled children in education. In this way, disabled children's experiences and voices are silenced (Millar \& Morton, 2007). 
The specific references that are made in the New Zealand Curriculum in relation to perceptions about dis/ability and academic achievement provide another example of deficit views of learning. Disabled children are referred to as having "special needs" whereas children (presumably not disabled) whose achievements are assessed as being above normal expectations, are referred to as having "special abilities" (MOE, 2007, p. 39). This communicates a set of assumptions about disability that includes the belief that if you are disabled, your identity as a learner should be interpreted in terms of deficit or need. This language constructs disabled people's 'special needs', their deviation from the norm, as their defining or most significant characteristic. Similarly, students who deviate through achieving significantly higher than average are labeled as above others or 'gifted'. A label such as having 'special abilities' indicates that the learner's perceived giftedness will be the major characteristic through which those student's learning and identity will be interpreted. As we have argued in relation to Clare and Maggie, there were negative consequences for their learning and participation when a view of them was restricted by pre-determined assumptions, rather than developing an understanding through a relationship with them as people and complex learners within a socio-cultural context. It is through a positioning as lacking and as 'other' that exclusionary practices can be both obscured and perpetuated. It is interesting how the positioning of disability as 'other' within the curriculum documents parallels the experiences of Clare and Maggie. The absence of any overt recognition of the need to identify and remove social and cultural barriers to disabled student's learning and participation, infers that a critical and contextualized consideration of disabled children's participation is unnecessary, irrelevant or unimportant.

\section{NZ Curriculum Documents \& a Pedagogy of Listening}

Through an ethics of care and obligation to the other, a 'pedagogy of listening' challenges the basing of teacher interpretations of learners on pre-conceived assumptions about a child or young person in relation to their membership of one particular group or identity. Perceiving a child's learning, behaviour and participation in relation to single aspects of their identity, such as their gender, ethnicity, socio-economic status, sexuality and/or (dis)-ability represents a simplistic, limited and hegemonic view of diversity and difference. Identities are multiple, changing, and fluid over contexts, relationships and time (Rinaldi, 2006). Rather than positioning learning and participation within the individual learner, socio-cultural approaches, such as a pedagogy of listening, recognize the social construction of knowledge, achievement and learning. It is our interrelationships within the lived contexts of our work, strongly influenced by the knowledge that we do and do not value, that impacts in concrete ways on the learning, participation and opportunities available to ourselves and others. Therefore, we must be alert and open to examining the effects of our thinking, practices and environments in order to recognize and remove barriers to the learning and participation of every child. It is crucial that as teachers we develop and take a critical, ethical and political stance and approach to our work rather than assuming that teaching, learning and developing 'inclusive environments' are straightforward and predictable processes. In order to practice inclusively, we must orient our practice and thinking towards listening to, understanding and being responsive to each and all of our diverse students, colleagues and families. 


\section{Narrative Assessment and Critical Teacher Reflection}

Recent New Zealand research in early childhood, primary and secondary school settings has suggested narrative approaches to assessment and teacher reflection are a potential way forward in transforming teaching and learning environments in ways that recognize and respond positively to disability and other expressions of diversity (Lepper, Williamson \& Cullen, 2003; MacArthur, Purdue \& Ballard, 2003; Macartney, 2009; Moore, et.al, 2008). Narrative approaches to assessment, such as Learning Stories, have the potential to support teachers understanding and developing a pedagogy based on a listening and open orientation to the learning, participation and contributions of their students. Teacher's use of narrative approaches to learning, teaching and assessment through the use of Learning Stories is widespread and commonly accepted practice throughout early childhood education settings in New Zealand (Carr, 2001; MOE, 2005, 2007). Narrative assessment encourages teachers to focus on children's learning and relationships within their particular setting, rather than applying de-contextualised and pre-conceived criteria to measure and compare children's performance in particular subject or skill areas (Carr, 2001). Narrative assessment also encourages and requires teacher to share, discuss and negotiate their interpretations of a child's learning and participation with others such as colleagues, parents and children. Moore, et.al (2008) reported that the teacher-writers trialing narrative assessment approaches through using Learning Stories in their primary and secondary school classrooms with disabled students, felt excited and empowered by the change from deficit based assessments to a credit based approach. Narrative approaches to assessment and the planning and teaching that those assessments led to, supported the teachers to notice, recognise and respond to their disabled student's learning, participation and achievements with far greater insight, positivity, relevance and depth than the norms referenced and criterion based methods they had previously used.

\section{Conclusion}

In this article, we have looked at our New Zealand curriculum documents and have pointed out the general support for inclusive educational approaches and environments within them. However, we have also argued that dominant deficit views of disability still work to limit many disabled children's learning, participation and access to the curriculum despite the documents' inclusive intentions. We have suggested that teachers need support to recognize the complex barriers to disabled children's learning and participation. Professional support around inclusive pedagogy should include on-going and critical reflection regarding teacher's own thinking, practices and environments. As a way forward, we have suggested that there is transformative potential in developing pedagogies based on an ethical and political commitment to recognizing and resisting inequality in our relationships, knowledge and settings. We have emphasised the importance of teachers developing a listening, open and responsive orientation to 'others' and have suggested that narrative approaches to assessment, planning and teacher reflection can be used to help teachers, early childhood and school environments to achieve this. 


\section{Bernadette Macartney \& Missy Morton}

\section{References}

Ballard. K. (2004). Children and disability: Special or included? Waikato Journal of education. Vol 10. pp.315-326

Bishop, R. Mazawi, A. \& Shields, C. (2005). Pathologizing practices: The impact of deficit thinking on education. New York: Peter Lang.

Carr, M. (2001). Assessment in early childhood settings: Learning stories. Paul Chapman Publishing: London.

Dalhberg \& Moss (2005) Ethics and politics in early childhood education. Contesting Early Childhood series. G. Dahlberg \& Moss, P. (Eds.). London \& New York: Routledge.

Dunn, L. (2004). Developmental assessment and learning stories in inclusive early intervention programmes: Two constructs in one context. NZ Research in Early childhood Education. 7, pp. 119 - 131.

Fleer, M. (2005). Developmental fossils — unearthing the artefacts of early childhood education: The reification of 'Child Development'. Australian Journal of Early Childhood. 30(2), pp. 2-10

Foucault, M. (1977) Discipline and punish: The birth of the prison. New York: Vintage Books, Random House.

Graham, L. (2005). The incidental "other”: A Foucaultian interrogation of educational policy effects. Paper presented at the AERA Conference, 11-15 April 2005, Montreal.

Gunn, A., Child, C., Madden, B., Purdue, K., Surtees, N., Thurlow, B. \& Todd, P. (2004).Building inclusive communities in early childhood education: Diverse perspectives from Aotearoa/New Zealand. Contemporary Issues in Early Childhood. 5(3), pp. 293-308.

Lepper, C., Williamson, D. \& Cullen, J. (2003). Professional development to support collaborative assessment. Early Education, Vol, 33 (Spring/Summer), pp. 19-38.

MacArthur, J. Purdue, K., \& Ballard, K. (2003). Competent and confident children? Te Whaariki and the inclusion of children with disabilities in early childhood education. In J.Nuttall (Ed.). Weaving Te Whaariki: Aotearoa New Zealand's early childhood curriculum document in theory and practice. Wellington: New Zealand Council for Educational Research. pp. 131 - 160.

MacArthur, J., Kelly, B. \& Higgins, N. (2005) Supporting the learning and social experiences of students with disabilities: What does the research say? In D.Fraser, R.Moltzen \& K.Ryba (Eds.) Learners with special needs in Aotearoa New Zealand ( $3^{\text {rd }}$ ed.). (pp.49-73). Australia: Thomson/Dunmore Press.

Macartney, B. (2002). Maggie-rose: A parent's story. The First Years/Nga Tau Tua Tahi: New Zealand Journal of Infant and Toddler Education, 4 (2), pp. 29-31.

Macartney, B. (2007). What is Normal and Why Does it Matter?: Disabling Discourse in Education and Society. Critical Literacy: Theories and practices journal, 1 (2), 29-41. Retrieved January 20, 2008 from World Wide Web: http:/www.criticalliteracy.org.uk/journal/table2.html

Macartney, B. (2008a). Disabled by the discourse: Some impacts of normalising mechanisms in education and society on the lives of disabled children and their families. NZ Research in Early Childhood Education. $1(11)$, pp. $33-50$

Macartney, B. (2008b). "If you don't know her, she can't talk": Noticing the tensions between deficit discourses and inclusive early childhood education. Early Childhood Folio. Vol, 12. pp 31 - 35 


\section{Bernadette Macartney \& Missy Morton}

Macartney, B. (2009). Teaching through an ethics of belonging, care and obligation as a critical approach to transforming education. Paper presented at the $9^{\text {th }}$ annual second city conference on Disability Studies in Education. Syracuse, New York State, USA. May 1-3.

Mac Naughton, G. (2005). Doing Foucault in early childhood studies: Applying poststructural ideas. London: Routledge.

Millar, R. \& Morton, M. (2007). Bridging two worlds: special education and curriculum policy. . International Journal of Inclusive Education,11(2),163-176

Ministry of Education (1996). Te Whaariki: Early childhood curriculum. He whaariki matauranga mo nga mokopuna o Aotearoa. Wellington: Learning Media.

Ministry of Education (1998). Quality in action/Te mahi whai hua: Implementing the revised statement of desirable objectives and practices in New Zealand early childhood services. Wellington: Learning Media.

Ministry of Education (2005, 2007). Kei tua o te pae assessment for learning: early childhood exemplars. Wellington: Learning Media.

Ministry of Education. (2007). The New Zealand Curriculum. Wellington: Learning Media.

Ministry of Health. (2001). The New Zealand disability strategy: Making a world of difference. Whakanui oranga. Wellington: Ministry of Education.

Moore, G., Molloy, S., Morton, M. \& Davis, K. (2008). Narrative assessment and equity for disabled students. Paper presented at the $34^{\text {th }}$ International Association for Educational Assessment Annual Conference. Cambridge, England. Sept 7-12.

Moss, P. \& Petrie, P. (2002). From children's services to children's speces: Public policy and childhood. London: RoutledgeFalmer.

Purdue, K. (2004). Inclusion and exclusion in early childhood education: Three case studies. Unpublished doctoral thesis. Dunedin, New Zealand: University of Otago.

Rinaldi, C. (2006). In dialogue with Reggio Emilia: Listening, researching and responding. Contesting Early Childhood Series. G. Dahlberg \& Moss, P. (Eds.). London \& New York: Routledge.

Rietveld, C.M. (2005) Teacher responses to children's spontaneous reactions to differences in their classmates with Down Syndrome: Implications for teaching and learning. Dunedin, New Zealand: New Zealand Association for Research in Education (NZARE) National Conference, 6-9 Dec 2005.

Robinson, K. \& Jones Diaz, C. (1999). Doing theory with early childhood educators: Understanding difference and diversity in personal and professional contexts. Australian Journal of Early Childhood. 24 (4). pp.33 - 39.

Skrtic, T. (1991). Behind special education: A critical analysis of professional culture and school organization. Colorado, USA: Love Publishing Company.

Smith, R. \& Barr, S. (2008). Towards educational inclusion in a contested society: From critical analysis to creative action. International Journal of Inclusive Education, 12(4), 401-422.

Veck, W. (2009). Listening to include. International Journal of Inclusive Education,13(2),141-155 